\title{
A Receptor Mechanism for the Inhibition of Insulin Release by Epinephrine in Man*
}

\author{
Daniel Porte, JR. $\dagger$ \\ (From the University of Washington and Veterans Administration Hospital, Department of \\ Medicine, Seattle, Wash.)
}

\begin{abstract}
Summary. Normal adult men and women have been infused with epinephrine, $6 \mu \mathrm{g}$ per minute, during lipolytic blockade with nicotinic acid, beta-adrenergic blockade with propranolol and Butoxamine, and alpha-adrenergic blockade with phentolamine. Epinephrine infusion was associated with low serum levels of immunoreactive insulin (IRI) except when phentolamine was given simultaneously. These findings are compatible with an alpha receptor mechanism for the epinephrine inhibition of insulin release. Phentolamine had no blocking effects on the tachycardia and widened pulse pressure or lipolytic stimulation by epinephrine, whereas both propranolol and Butoxamine blocked lipolysis, tachycardia, and widened pulse pressure. These findings are consistent with an alpha receptor blocking action for phentolamine and beta receptor blocking action for propranolol and Butoxamine. Inhibition of lipolysis by nicotinic acid did not alter IRI or glucose responses to epinephrine. It is concluded that the lipolytic effect of epinephrine is unrelated to its effects on IRI release. Lipolytic blockade by nicotinic acid also did not change IRI or glucose in fasting subjects or their responses to a glucose infusion, $300 \mathrm{mg}$ per minute. These observations appear to conflict with the Randle hypothesis (the glucose-fatty acid cycle) and raise some doubt as to whether plasma FFA concentrations are direct determinants of glucose or IRI concentrations in normal man.
\end{abstract}

\section{Introduction}

Infusions of epinephrine (1) and norepinephrine (2) recently have been shown to inhibit the release of serum immunoreactive insulin in man.

* Submitted for publication June 9, 1966; accepted September 22, 1966.

Supported in part by grants AM-02456, T1-AM-5020, and AM-06670 from the National Institute of Arthritis and Metabolic Diseases. A portion of the study was conducted at the Clinical Research Center facility of the University of Washington (grant FR-37 from the National Institutes of Health).

Presented in part before a joint meeting of the American Society for Clinical Investigation and the American Federation for Clinical Research, May 1, 1966, Atlantic City, N. J.

$\dagger$ Clinical Investigator, Veterans Administration Hospital, Seattle, Wash.

Address requests for reprints to Dr. Daniel Porte, Jr., Veterans Administration Hospital, 4435 Beacon Ave. S., Seattle, Wash. 98108.
This inhibition of insulin release also has been demonstrated in pancreatic slices in vitro (3), by pathologic study of the pancreas (4), and by measurements of pancreatic venous blood insulin levels in animals in vivo (5). Therefore, catecholamines presumably have a direct action on the secretion of insulin by pancreatic beta cells. Both the in vitro and in vivo effects are blocked by prior administration of dihydroergotamine $(3,4)$, suggesting that adrenergic receptors similar to those responsible for the effects of catecholamines on muscle are involved. Two types of catecholamine receptor (alpha and beta) are presently believed to explain most of the results obtained in catechol stimulation studies, and a nomenclature proposed by Ahlquist (6) has been generally adopted to separate these receptors on a functional basis. The specific receptor responsible for the inhibiting effects of catecholamines upon insulin secretion 
TABLE I

A classification of some of the properties of catecholamine stimulation and blocking agents used in this study*

\begin{tabular}{|c|c|c|c|c|c|}
\hline Physiologic effect & $\begin{array}{l}\text { Receptor } \\
\text { type }\end{array}$ & $\begin{array}{c}\text { Propranolol } \\
\text { ( } \boldsymbol{\beta} \text { blocker })\end{array}$ & $\begin{array}{l}\text { Butoxamine } \\
(\boldsymbol{\beta} \text { blocker } t)\end{array}$ & $\begin{array}{l}\text { Phentolamine } \\
\text { ( } \alpha \text { blocker })\end{array}$ & $\begin{array}{c}\text { Nicotinic acid } \\
\text { (nonadrenergic } \\
\text { blocking agent) }\end{array}$ \\
\hline Tachycardia & $\beta$ & + & + & $0 \neq$ & 0 \\
\hline Arterial vasoconstriction & $\alpha$ & 0 & $\mathbf{0}$ & + & 0 \\
\hline Arterial vasodilation & $\beta$ & + & + & 0 & 0 \\
\hline Inhibition of intestinal motility & $\alpha$ and $\beta$ & Partial & Partial & Partial & 0 \\
\hline Bronchodilation & $\beta$ & + & + & 0 & $\mathbf{0}$ \\
\hline $\begin{array}{l}\text { Accelerated muscle glycogenolysis } \\
\quad(\uparrow \text { blood lactic acid }) \|\end{array}$ & $\beta$ & + & + & 0 & 0 \\
\hline $\begin{array}{l}\text { Increased lipolysis in adipose tissue } \\
(\uparrow \text { plasma FFA })\end{array}$ & $\beta$ & + & + & 0 & + \\
\hline
\end{tabular}

* + indicates the drug to be an effective blocking agent. 0 indicates no effect.

$\dagger$ May have other metabolic effects unrelated to catecholamine blocking effects.

$\ddagger$ May cause tachycardia when given alone.

$\S \beta$ receptors may be present in some species.

|| Increased cycling of lactic acid to glucose in the liver may raise blood sugar.

has not been elucidated because $a$ ) both epinephrine and norepinephrine stimulate both alpha and beta receptors, and $b$ ) ergotamine derivatives have been shown to block both alpha and beta receptor responses $(7-10)$. During the past 5 years newer drugs that are more selective in their ability to block either alpha or beta receptors have been described (Table I). These compounds have been used in the present study to define the receptor mechanism for the inhibition of insulin release by epinephrine.

\section{Methods}

Subjects selected were all ambulatory, apparently normal young adult men and women. A total of twenty studies were performed on nine men and six women. Volunteers were excluded if they exceeded their ideal body weight by more than $15 \%^{1}$ or if there was a family history of diabetes mellitus. Some of the subjects were studied more than once. All subjects continued to eat their regular diet, but on the night before the study they were instructed to take no solid food after the evening meal and no liquids except water after midnight. No smoking was allowed on the day of the test. The volunteer subject on arrival at the Clinical Research Center was put to bed, and a slow intravenous drip of $0.85 \%$ sodium $\mathrm{NaCl}$ was begun through each of two indwelling venous plastic catheters. Blood samples were withdrawn through one catheter and drugs and glucose infused through the other. No anticoagulants were given to the patient or were present in the sampling syringes. Blood samples were taken every 15 minutes and kept at $4^{\circ} \mathrm{C}$ until the end of the study. At this time heparinized samples were centrifuged at $4^{\circ} \mathrm{C}$, and

1 Calculated from statistical tables of the Metropolitan Life Insurance Co. the separated plasma was frozen at $-19^{\circ} \mathrm{C}$ for future analysis of glucose and free fatty acids. Blood samples for measurement of IRI were allowed to clot for 1 hour

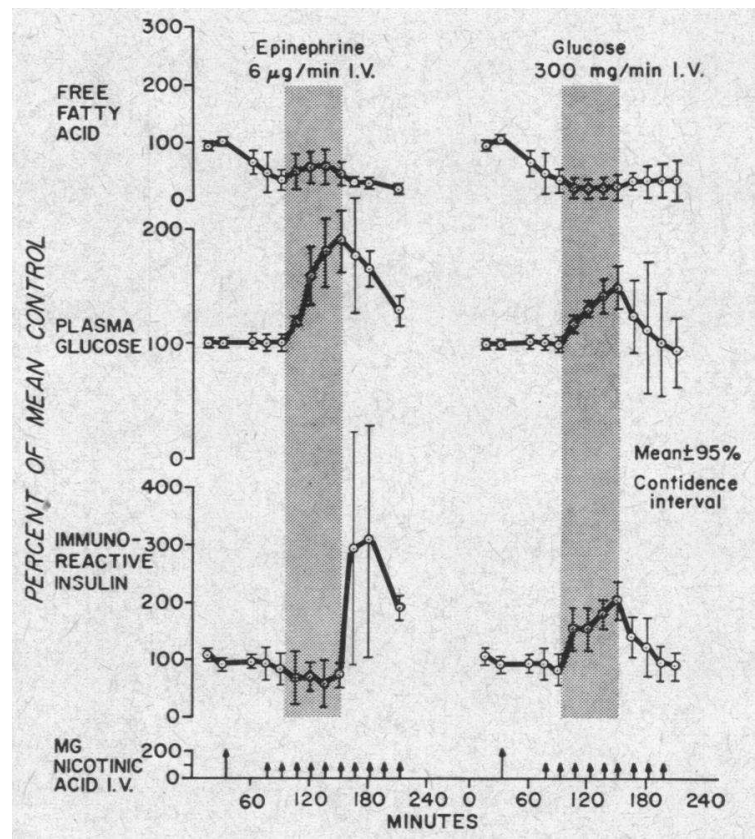

Fig. 1. The effect of intravenous nicotinic acid ON THE FREE FATTY ACID, PLASMA GLUCOSE, AND SERUM IMMUNOREACTIVE INSULIN RESPONSES TO EPINEPHRINE AND GLUCOSE INFUSIONS. A mean of the first two observations is set at $100 \%$. All values are expressed as a per cent of this mean control. Each pair of brackets represents the $95 \%$ confidence limit of the mean value. Brackets that do not overlap are significant at the $p<$ 0.05 level. Four subjects were tested. Two received epinephrine first; two received glucose first. The data from the four infusions are pooled for presentation. The response to nicotinic acid in fasting subjects appears twice. 
DANIEL PORTE, JR.

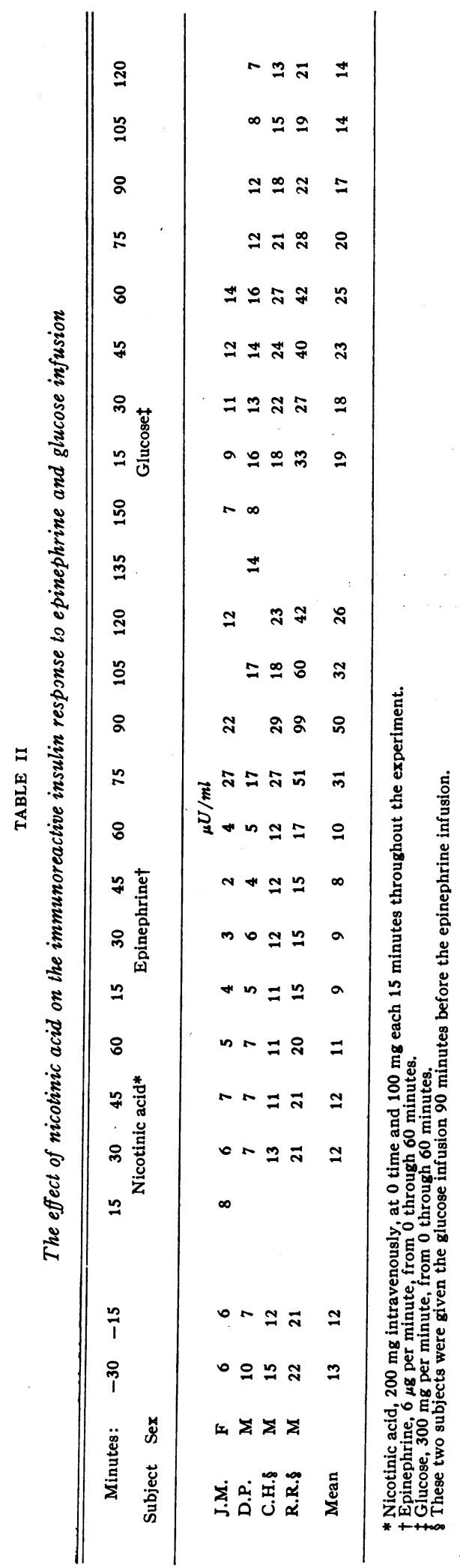

at room temperature, and the serum was then separated from the clot and frozen at $-19^{\circ} \mathrm{C}$ until analyzed for IRI by the double antibody immunoprecipitation technic (11) modified from Morgan and Lazarow (12). Free fatty acids were titrated against standard base by a modified Dole procedure (13). Plasma glucose was measured by a Technicon Autoanalyzer with a ferricyanide reagent (14) or by a modification of the glucose oxidase technic (15). Nicotinic acid, ${ }^{2} 10 \mathrm{mg}$ per ml, phentolamine, ${ }^{3}$ and epinephrine ${ }^{4}$ were commercially available. Propranolol $^{5}$ and tertiary butyl methoxamine ${ }^{6}$ were supplied for phase I clinical investigation studies. When epinephrine infusions were given, auto-oxidation was prevented by the addition of ascorbic acid, $2.5 \mathrm{mg}$ per $\mathrm{ml}$ of infused solution.

\section{Results}

Nicotinic acid. Nicotinic acid was given as a single injection of $200 \mathrm{mg}$ followed by $100 \mathrm{mg}$ every 15 minutes just after a blood sample was withdrawn. Seventy-five or 90 minutes after the initiation of nicotinic acid therapy, epinephrine (6 $\mu \mathrm{g}$ per minute) or glucose (300 $\mathrm{mg}$ per minute) was infused. A total of four subjects were studied. In two subjects the glucose was given first, and in two the epinephrine was given first. A 90 -iminute interval was allowed between infusions when glucose was given first, 150 minutes when epinephrine was given first. Since the data were comparable for the two studies, Figure 1 and Table II represent the pooled response to glucose and epinephrine of all four subjects. For clarity of presentation, the first 90 minutes of observation before the infusion of epinephrine or glucose is repeated in both graphs. The basal level of free fatty acids was decreased by nicotinic acid to $25 \%$ of the mean control value, before the infusion of either epinephrine or glucose. There was no change in either IRI or glucose during this time. The infusion of epinephrine was associated with marked hyperglycemia but no change in basal level of immunoreactive insulin. Fifteen minutes after the epinephrine was stopped, there was a prompt rise in IRI levels to a peak 15 minutes after the infusion. In contrast, in the same four subjects there was a prompt rise in insulin levels during the infusion of glucose, which decreased

2 Eli Lilly, Indianapolis, Ind.

${ }^{3}$ Regitine, Ciba Pharmaceutical Co., Summit, N. J.

4 Parke Davis and Co., Detroit, Mich.

5 Inderal, Ayerst Laboratories, New York, N. Y.

- Butoxamine, Burroughs Wellcome and Co., Tuckahoe, N. Y. 
parallel to the fall in blood sugar after the infusion was stopped. These IRI and glucose responses were similar in magnitude to those previously found with epinephrine or glucose alone without nicotinic acid blockade of free fatty acid mobilization (1). All subjects showed the expected tachycardia and widened pulse pressure during the epinephrine infusion.

Propranolol. After a control period of 1 hour, $5 \mathrm{mg}$ of propranolol was given as a single intravenous injection to five subjects, and 5 to 15 minutes later an infusion of epinephrine, $6 \mu \mathrm{g}$ per minute, and propranolol, $0.08 \mathrm{mg}$ per minute, was begun for 1 hour in four subjects. In four of the five subjects, a single blood sample taken 5 minutes after the single injection of $5 \mathrm{mg}$ of propranolol showed no change in basal FFA, IRI, or glucose, nor were basal values altered in two subjects measured at 15 minutes. During the infusion of epinephrine in four subjects, lipolysis stimulated by epinephrine was almost completely inhibited by the simultaneous administration of propranolol ( Figure 2). Hyperglycemia still occurred and was of the same order of magnitude as found previously with epinephrine alone (1) or during nicotinic acid treatment. Serum IRI levels fell during the combined infusions to approximately $50 \%$ of the mean control levels in fasting subjects (Table III). This fall resulted in IRI levels significantly lower than basal and lower than those found with nicotinic acid in the present report or than those previously reported with epinephrine alone (1). After cessation of the combined infusions, there was the usual prompt

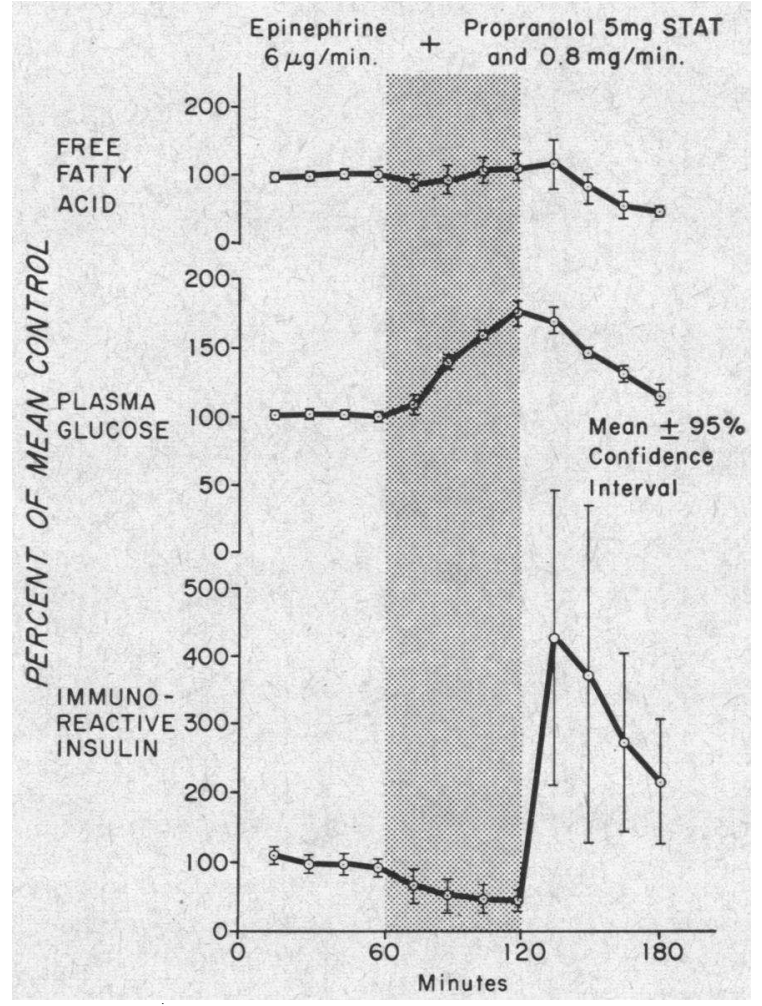

Fig. 2. The effect of intravenous propranolol on THE FREE FATTY ACID, PLASMA GLUCOSE, AND SERUM IMMUNOREACTIVE INSULIN RESPONSES TO EPINEPHRINE INFusion. Four subjects. See Figure 1. Stat. = at once.

rise in IRI levels. During the combined propranolol-epinephrine infusion all subjects were found to have mild hypertension and bradycardia rather than tachycardia and widened pulse pressure.

Butoxamine. Butoxamine was given to five subjects orally. The first subject received $3 \mathrm{mg}$

TABLE III

The effect of propranolol on the immunoreactive insulin response to an epinephrine infusion

\begin{tabular}{|c|c|c|c|c|c|c|c|c|c|c|c|c|c|c|c|c|c|c|c|}
\hline \multicolumn{2}{|c|}{ Minutes: } & -60 & -45 & -30 & -15 & 5 . & 10 & 15 & 30 & 45 & 60 & 75 & 90 & 105 & 120 & 135 & 150 & 165 & \\
\hline Subject & Sex & & & & & \multicolumn{3}{|c|}{ Propranolol* } & \multicolumn{4}{|c|}{ Epinephrinet } & & & & & & & \\
\hline \multicolumn{19}{|c|}{$\mu U / m l$} & \\
\hline J.L. & $\mathbf{F}$ & 10 & 10 & 9 & 10 & 10 & & 10 & 10 & 8 & 6 & 7 & 21 & 14 & 24 & 12 & . & 9 & \\
\hline \multicolumn{19}{|c|}{$\begin{array}{c}\text { Epinephrinet } \\
\text { and } \\
\text { propranolol } \ddagger\end{array}$} & \\
\hline R.R. & $\mathbf{M}$ & 15 & 14 & 15 & 12 & & & & 7 & 5 & 5 & 5 & 59 & 66 & 40 & 29 & & 14 & \\
\hline M.M. & $\mathbf{M}$ & 8 & 8 & 9 & 8 & 8 & & & 5 & 4 & 4 & 4 & 36 & 43 & 31 & 24 & 21 & 20 & \\
\hline M.G. & $\mathbf{F}$ & 7 & 8 & 6 & 7 & 6 & & & 5 & 4 & 3 & 3 & 40 & 19 & 16 & 12 & & 10 & \\
\hline K.C. & F & 8 & 7 & 6 & 7 & 7 & 7 & 7 & 6 & 5 & 5 & 4 & 18 & 15 & 14 & 14 & & & \\
\hline Mean & & 10 & 9 & 9 & 9 & 8 & & & 7 & 5 & 5 & 5 & 35 & 31 & 27 & 18 & & 13 & \\
\hline
\end{tabular}

* Propranolol, $5 \mathrm{mg}$, at 0 time.

$\dagger$ Epinephrine, $6 \mu \mathrm{g}$ per minute, for 60 minutes from 16 through 75 minutes.

¥ Propranolol, .08 $\mathrm{mg}$ per minute, for 60 minutes from 16 through 75 minutes. 


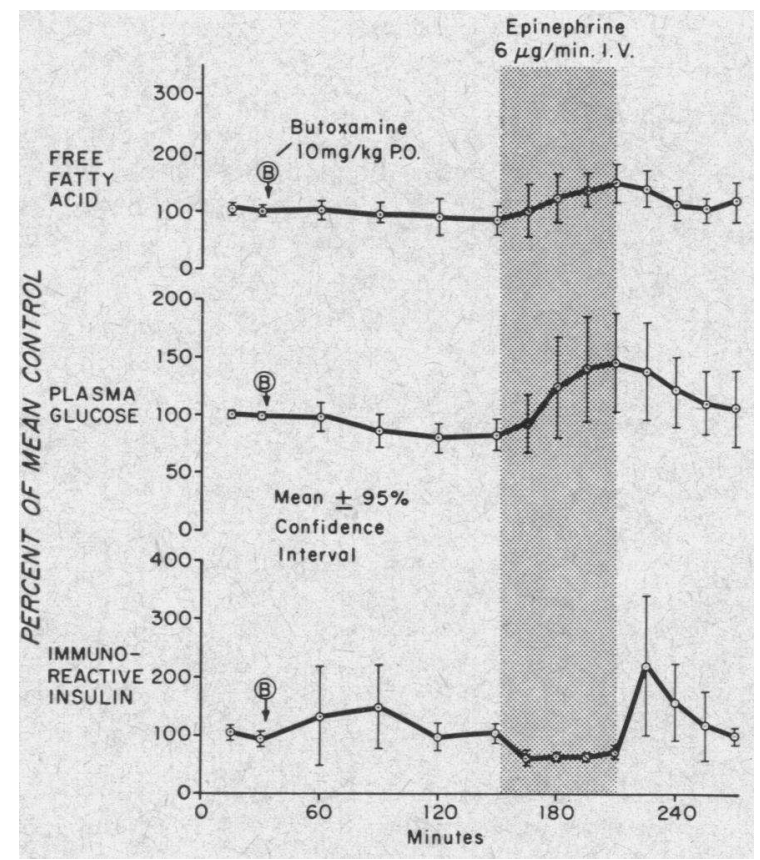

Fig. 3. The effect of ORAL (P.O.) bUtoxamine on THE FREE FATTY ACID, PLASMA GLUCOSE, AND SERUM IMMUNOREACTIVE INSULIN RESPONSES TO EPINEPHRINE. Four subjects. See Figure 1.

per $\mathrm{kg}$, and although this dose was adequate for blockade of the cardiovascular effects of epinephrine, stimulation of lipolysis and glycogenolysis still occurred. Therefore, the next four subjects were given $10 \mathrm{mg}$ per $\mathrm{kg}$. Two hours after the ingestion of the drug each subject was infused with $6 \mu \mathrm{g}$ of epinephrine per minute for 1 hour. During the 2-hour preinfusion period, there was a small fall in both glucose and free fatty acids in the four subjects shown in Figure 3. Both measurements dropped to $80 \%$ of control values, but only the glucose drop was statistically significant from control $(\mathrm{p}<0.05)$ for the 120 - and 150-minute points. The fifth subject given the smaller dose showed the same fall in both parameters. IRI showed a small and variable rise for the 30-and 60-minute specimens after Butoxamine. Although four of the five subjects showed this change, the mean response was not significant because of its variability in time and magnitude (Table IV). During the infusion of epinephrine, lipolysis was blocked by about $50 \%$; blood sugar levels were slightly lower than those found with epinephrine alone (1) or with epinephrine and nicotinic acid or propranolol blockade. IRI levels decreased to approximately $50 \%$ of control and were similar to those found during propranolol blockade of epinephrine. These levels were significantly lower than those found during the nicotinic acid study or with epinephrine alone (1). After the epinephrine infusion, there was the usual prompt rebound in serum IRI. Pretreatment of these subjects with Butoxamine prevented the usual tachycardia and widened pulse pressure produced by epinephrine. Instead, mild bradycardia and slight hypertension were found. The patients had no subjective sensations of nervousness or tremor as is usually found during epinephrine infusions.

Phentolamine. After a control period of 1 hour, five subjects were given a single rapid injection of $5 \mathrm{mg}$ of phentolamine followed by a continuous infusion of phentolamine, $0.5 \mathrm{mg}$ per minute, and epinephrine, $6 \mathrm{mg}$ per minute for 1 hour. The glucose rise during these infusions was less than was found without phentolamine (1) or during nicotinic acid blockade. Free fatty

TABLE IV

The effect of oral Butoxamine on the immunoreactive insulin response to an epinephrine infusion

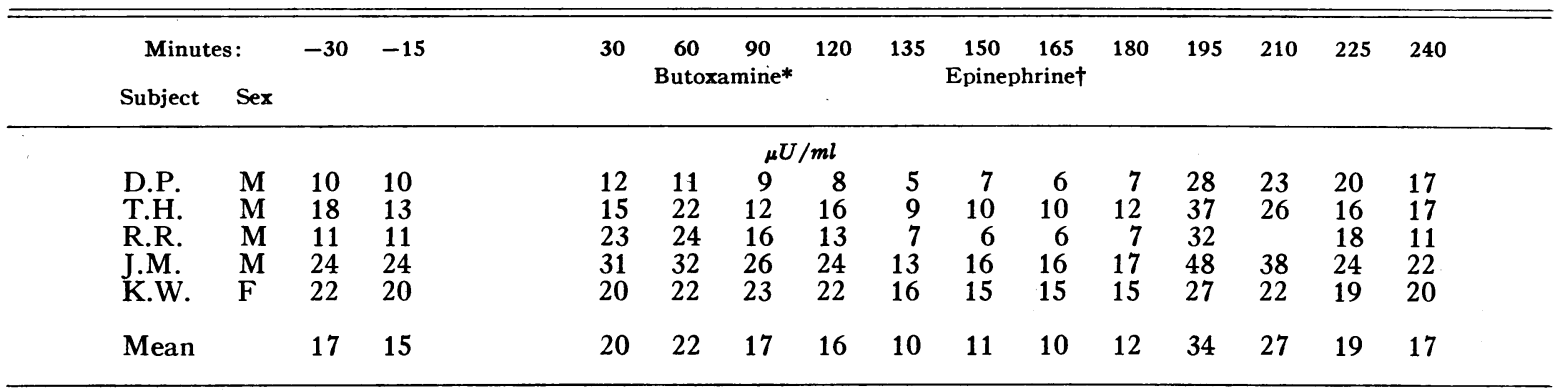

* Butoxamine, $3 \mathrm{mg}$ per $\mathrm{kg}$ in D.P., $10 \mathrm{mg}$ per $\mathrm{kg}$ in other subjects at 0 time.

$\dagger$ Epinephrine, $6 \mu \mathrm{g}$ per minute intravenously, from 121 through 180 minutes. 


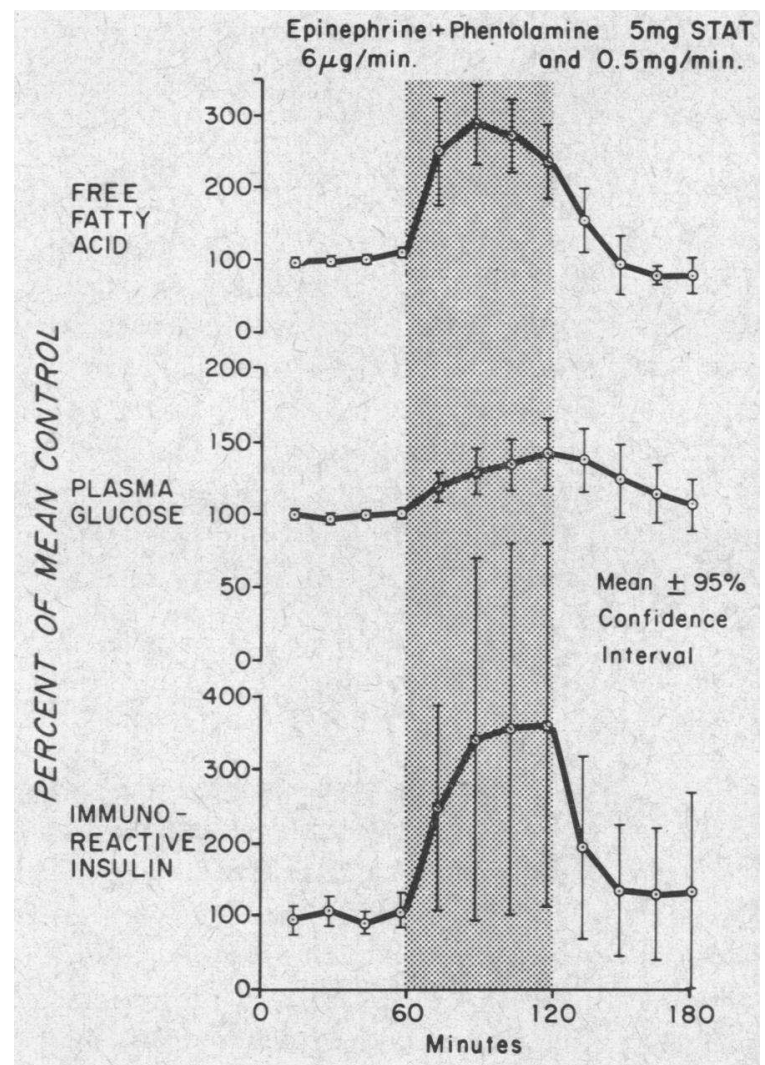

Fig. 4. The efFect of IntRavenous Phentolamine (REgitine) ON THE FReE FAtTy ACID, PLASMa GLUCOSE, AND SERUM IMMUNOREACTIVE INSULIN RESPONSES TO EPINEPHRINE. Five subjects. See Figure 1.

acid stimulation of lipolysis was comparable to that found with epinephrine alone (1). IRI levels, however, were strikingly different and were elevated in all subjects at all times during the infusions (Figure 4, Table V). After the infusions there was not the usual rebound in IRI but a

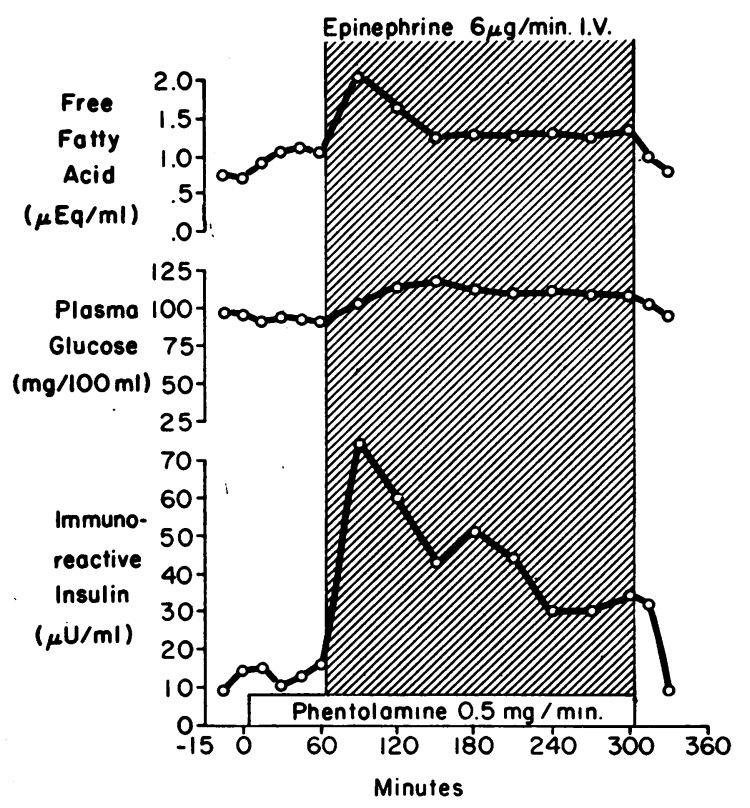

Fig. 5. The efFect of intravenous phentolamine ON THE CONCENTRATIONS OF FREE FATTY ACID, PLASMA GLUCOSE, AND SERUM IMMUNOREACTIVE INSULIN IN FASTING SUBJECTS. After phentolamine had been infused for 1 hour, epinephrine was given together with phentolamine for an additional 4 hours. Subject R.R.

progressive fall similar to that found after glucose infusions. The magnitude of the IRI rise was quite variable (Table V), and this is reflected in the wide 95\% confidence intervals found in Figure 4.

Four other subjects were given phentolamine alone. Two of them received infusions for 30 minutes and one for a full hour in a manner similar to the infusion of epinephrine. The fourth subject was given phentolamine for an hour preceding

TABLE $V$

The effect of phentolamine on the immunoreactive insulin response to an épinephrine infusion

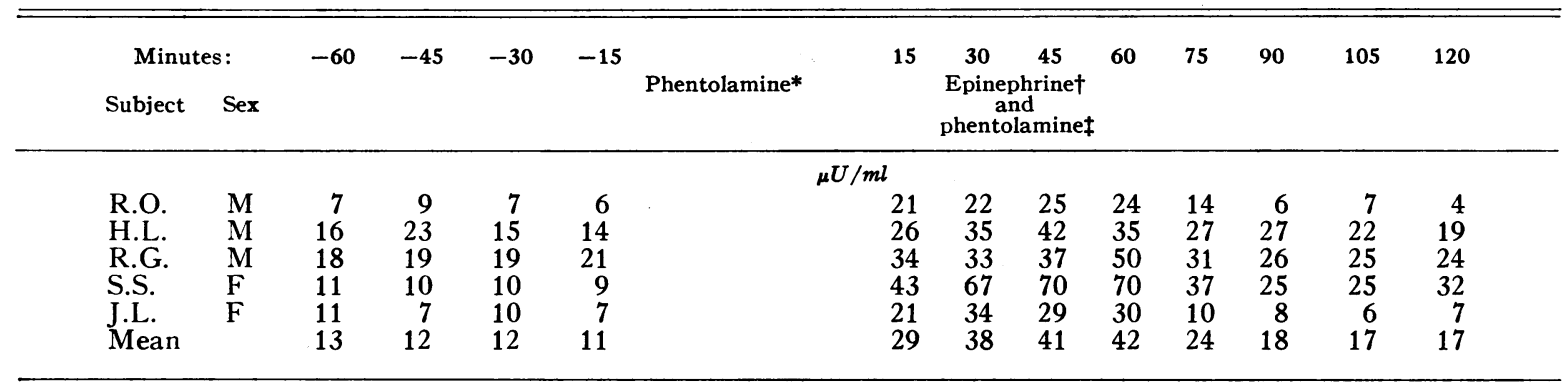

* Phentolamine, $5 \mathrm{mg}$, at 0 time.

$\dagger$ Epinephrine, $6 \mu \mathrm{g}$ per minute for 60 minutes.

$\ddagger$ Phentolamine, $0.5 \mathrm{mg}$ per minute for 60 minutes. 
and also during a 4-hour epinephrine infusion (Figure 5). None of the subjects given phentolamine alone showed any change in plasma glucose or serum IRI. In two there was a small and variable rise in FFA. All showed tachycardia and widened pulse pressure with phentolamine alone, and similar tachycardia and widened pulse pressure was found in all subjects given the combined phentolamine and epinephrine infusion. Although the combined phentolamine and epinephrine infusions had decreased the plasma glucose response to epinephrine somewhat, the one subject (R.R.) given phentolamine, both before and during epinephrine (Figure 5), showed a much greater inhibition of glucose rise. In this subject, the maximal concentration of plasma glucose was $113 \mathrm{mg}$ per $100 \mathrm{ml}$ after 1 hour of epinephrine infusion, whereas it was $180 \mathrm{mg}$ per $100 \mathrm{ml}$ with nicotinic acid blockade and $166 \mathrm{mg}$ per $100 \mathrm{ml}$ with epinephrine alone (1).

\section{Discussion}

The concept that catecholamines produce effects by stimulating two types of receptors was originally proposed by Ahlquist (6) in studies involving skeletal, smooth, and cardiac muscle. His conclusions have been amply confirmed, but until recently there has been considerable confusion about the applicability of this concept to the known lipolytic and glycogenolytic stimulation by catecholamines. This confusion appears to have been resolved by more recent studies which show that both lipolysis in adipose tissue and glycogenolysis in liver and muscle can also be explained by a two receptor theory. Specifically, free fatty acid mobilization from adipose tissue and glycogenolysis in muscle appear to be beta-adrenergic effects (16-18), whereas glycogenolysis in liver appears to be primarily a specific alpha-adrenergic receptor effect (18), although beta receptor function has not been completely excluded in some species. The inhibition of insulin release by epinephrine was reversed only by simultaneous infusion of phentolamine. Most previous studies of this drug have been consistent with an alpha blockade action (19). There was no inhibition of the lipolytic properties of epinephrine and no blockade of the usual tachycardia and widened pulse pressure. Although the latter observation is somewhat diffi- cult to interpret, because phentolamine infusion alone will cause tachycardia and widened pulse pressure, both are consistent with an alpha receptor blockade, since free fatty acid mobilization, cardiac stimulation, and vasodilation are considered to be beta-stimulating effects of epinephrine (vida supra). The elevated IRI during phentolamine and epinephrine infusions was associated with significantly lower plasma glucose levels than were found during epinephrine infusions with nicotinic acid or propranolol, or during epinephrine infusion alone (1). The lower glucose level presumably in part reflects the higher IRI response, but could be partly or entirely related to other effects of phentolamine upon epinephrinestimulated glycogenolysis in muscle or liver. The study does not allow an independent evaluation of these possibilities.

Propranolol, which has been reported to produce a specific beta-adrenergic blockade (20), was associated during epinephrine infusions with IRI levels that fell significantly below basal, rather than remaining unchanged as found with epinephrine alone (1) or epinephrine and nicotinic acid. The present studies are completely compatible with a beta-adrenergic mechanism for propranolol blockade, since free fatty acid release was almost totally inhibited and tachycardia and widened pulse pressure were replaced by bradycardia and hypertension. Pretreatment with Butoxamine produced similar changes in both IRI and FFA, although the free fatty acid blockade was less complete. These effects were to be expected if the beta-adrenergic properties of epinephrine were blocked by both drugs, leaving the alpha-adrenergic-stimulating effects unhindered. The similar depression of basal insulin values (an exaggeration of the inhibiting effect of epinephrine) by these two drugs suggests either that stimulation of beta receptors releases insulin or that blockade of the beta-stimulating properties of catecholamines in some way enhances the IRI-inhibiting alpha-adrenergic effects. In other studies (21) isoproterenol, an apparently specific beta-stimulating catecholamine, has been found to stimulate insulin release in the absence of hyperglycemia. This observation would favor the latter hypothesis that beta stimulation by epinephrine results in stimulation of insulin release. Blockade of this beta stimulation would then be one possible ex- 
planation for the fall of IRI during epinephrine infusions with Butoxamine and propranolol. Intravenous propranolol had no acute effect on fasting free fatty acids, glucose, or IRI (five subjects at 5 minutes, two at 15 minutes), but oral Butoxamine reduced both free fatty acids and glucose in fasting subjects. The mechanism for the fall in basal free fatty acid and glucose after Butoxamine is not clear from our study, but it is of interest that four of the five subjects showed small increases in IRI 30 and 60 minutes after the drug had been given. Although the magnitude of these IRI changes was quite variable, it seems possible that insulin release by Butoxamine might be related to an initial beta-adrenergic stimulation by the drug, causing effects similar to isoproterenol infusion (21). Further studies seem necessary to evaluate this possibility.

Nicotinic acid has been shown to localize in adipose tissue and to block many hormonally induced stimuli to free fatty acid mobilization (22). The present studies reaffirm this blocking effect in normal man. If the effect of epinephrine on insulin release were due to a specific adrenergic mechanism, one would not expect that blocking lipolysis would in any way change the response of IRI to epinephrine infusion. Since this was observed, it would appear that the lipolytic effect of epinephrine is totally unrelated to its inhibition of IRI release. The additional observation that lowering free fatty acids to $25 \%$ of their usual levels had no effect on fasting glucose or IRI, or on the IRI response to a small glucose challenge, is of particular interest. Randle, Garland, Hales, and Newsholme proposed from extensive in vitro studies that free fatty acid levels were important regulators of glucose entry into cells (23). If this hypothesis were applicable to man, one would expect that marked changes in FFA in fasting subjects would be reflected by changes in either fasting glucose or IRI or both. One might also expect that the IRI or glucose response to a glucose load would be altered. The present observations do not confirm this hypothesis, since glucose and IRI concentrations were comparable to those observed previously without nicotinic acid blockade of FFA mobilization (1). Further studies seem necessary, therefore, before the Randle hypothesis can be applied without modification to normal man.

\section{Acknowledgments}

The author wishes to thank Mrs. Susan Page for her enthusiastic participation in the conduct of these studies and for her skillful technical assistance. They were begun in the laboratory of $\mathrm{Dr}$. R. H. Williams to whom the author is indebted for continued support and encouragement.

\section{References}

1. Porte, D., Jr., A. Graber, T. Kuzuya, and R. H. Williams. The effect of epinephrine on immunoreactive insulin levels in man. J. clin. Invest. 1966, 45, 228.

2. Porte, D., Jr., and R. H. Williams. Inhibition of insulin release by norepinephrine in man. Science 1966, 152, 1248.

3. Coore, H. G., and P. J. Randle. Regulation of insulin secretion with pieces of rabbit pancreas incubated in vitro. Biochem. J. 1964, 93, 66.

4. Loubatières, A., M. M. Mariani, J. Chapal, J. Taylor, M. H. Houareau, and A. M. Rondot. Action nocive de l'adrénaline pour la structure histologique des ilots de Langerhans du pancréas. Action protectrice de la dihydroergotamine. Diabetologia 1965, 1, 13.

5. Kosaka, K, T. Ide, T. Kuzuya, E. Miki, N. Kuzuya, and S. Okinaka. Insulin-like activity in pancreatic vein blood after glucose loading and epinephrine hyperglycemia. Endocrinology 1964, 75, 9.

6. Ahlquist, R. P. A study of the adrenotropic receptors. Amer. J. Physiol. 1948, 153, 586.

7. Goodman, H. M., and E. Knobil. Effect of adrenergic blocking agents on fatty acid mobilization during fasting. Proc. Soc. exp. Biol. (N. Y.) 1959, 102, 493.

8. Harvey, S. C., C. Y. Wang, and M. Nickerson. Blockade of epinephrine-induced hyperglycemia. J. Pharmacol. exp. Ther. 1952, 104, 363.

9. McElroy, W. T., Jr., and J. J. Spitzer. Effects of adrenergic blocking agents on plasma free fatty acid concentrations. Amer. J. Physiol. 1961, 200, 318.

10. Levy, B., and R. P. Ahlquist. An analysis of adrenergic blocking activity. J. Pharmacol. exp. Ther. 1961, 133, 202.

11. Samols, E., and D. Bilkus. A comparison of insulin immunoassays. Proc. Soc. exp. Biol. (N. Y.) 1964, 115, 79.

12. Morgan, C. R., and A. Lazarow. Immunoassay of insulin: two antibody system. Plasma insulin levels of normal, subdiabetic and diabetic rats. Diabetes 1963, 12, 115.

13. Trout, D. L., E. H. Estes, Jr., and S. J. Friedberg. Titration of free fatty acids in plasma: a study of current methods and a new modification. J. Lipid Res. 1960, 1, 199. 
14. Technicon Autoanalyzer Methodology. Method File. Rev. February 11, 1960. Chauncey, N. Y., Technicon Instruments Corp.

15. Saifer, A., and S. Gerstenfeld. The photometric microdetermination of blood glucose with glucose oxidase. J. Lab. clin. Med. 1958, 51, 448.

16. Pilkington, T. R. E., R. D. Lowe, R. Foster, B. F. Robinson, and A. Antonis. Effect of sympathomimetic compounds with $\beta$-adrenergic effects on plasma free fatty acids in man. J. Lipid Res. 1966, $7,73$.

17. Vrij, C., Jr., B. K. Gho, C. A. De Groot, and J. F. Weber. The effect of isopropyl-nor-adrenaline and nor-adrenaline on the glycogen content of skeletal muscle and liver of the rat. Acta physiol. pharmacol. neerl. 1956, 4, 547.

18. Fleming, W. W., and A. D. Kenny. The effect of fasting on the hyperglycaemic responses to catechol amines in rats. Brit. J. Pharmacol. 1964, 22, 267.
19. Moran, N. C., and M. E. Perkins. An evaluation of adrenergic blockade of the mammalian heart. $\mathrm{J}$. Pharmacol. exp. Ther. 1961, 133, 192.

20. Nakano, J., and T. Kusakari. Competitive antagonism between isoproterenol and a new beta-receptor adrenergic blocking agent, propranolol. Proc. Soc. exp. Biol. (N. Y.) 1965, 119, 350.

21. Porte, D., Jr., A Graber, and R. H. Williams. The effect of catecholamines upon insulin levels in man (abstract). Proceedings of the VI Pan-American Congress of Endocrinology, 1965, p. E-15.

22. Carlson, L. A., and P. R. Bally. Inhibition of lipid mobilization in The Handbook of Physiology, Section 5, Adipose Tissue, A. E. Renold and G. F. Cahill, Jr., Eds. Baltimore, Williams \& Wilkins, 1965 , p. 557.

23. Randle, P. J., P. B. Garland, C. N. Hales, and E. A. Newsholme. The glucose fatty-acid cycle. Its role in insulin sensitivity and the metabolic disturbances of diabetes mellitus. Lancet 1963, 1, 785. 